\title{
Synthesis of silver nanoparticles using marine macroalgae Padina sp. and its antibacterial activity towards pathogenic bacteria
}

\author{
Prakash Bhuyar ${ }^{1}$, Mohd Hasbi Ab. Rahim ${ }^{1,2}$, Sathyavathi Sundararaju ${ }^{3}$, Rameshprabu Ramaraj ${ }^{4}$, \\ Gaanty Pragas Maniam ${ }^{1,2}$ and Natanamurugaraj Govindan ${ }^{1,2^{*}}$ (D)
}

\begin{abstract}
Background: Marine algae used as a food source for ocean life and range in color from red to green to brown grow along rocky shorelines around the world. The synthesis of silver nanoparticles by marine alga Padina sp. and its characterization were fulfilled by using UV-visible spectrophotometer, Fourier transform infrared spectroscopy, scanning electron microscopy and field emission scanning electron microscopy, and energy-dispersive X-ray spectroscopy.

Results: UV-visible absorption spectrum revealed that the formation of Ag nanoparticles was increased by the addition of marine algae and the spectral peak observed between a wavelength of $\sim 420 \mathrm{~nm}$ and $445 \mathrm{~nm}$. In addition, SEM and FESEM images examined the surface morphology and the size of the synthesized NPs was relatively uniform in size $\sim 25-60 \mathrm{~nm}$. Energy-dispersive X-ray spectroscopy analysis confirmed the purity of Ag NPs with atomic percentage of $48.34 \% \mathrm{Ag}$. The synthesized Ag NPs showed highly potent antibacterial activity. The Staphylococcus aureus and Pseudomonas aeruginosa were found to be more susceptible to silver nanoparticles by forming $15.17 \pm 0.58 \mathrm{~mm}$ and $13.33 \pm 0.76 \mathrm{~mm}$ of diameter of the inhibition zone, respectively.

Conclusions: The study suggested that marine alga Padina sp. could be an alternative source for the production of Ag nanoparticles and are efficient antimicrobial compounds against both gram-negative and gram-positive bacteria which can be a promising material against infectious bacteria.
\end{abstract}

Keywords: Marine algae, Padina sp., Silver nanoparticles, Antimicrobial activity

\section{Background}

Marine macroalgae, or marine algae, are plant-like organisms or other hard substrata in coastal areas [1]. They commonly attached to rocks, sand, dead plants, and algae of undersea, or even caught on the sea and ocean surfaces [2]. The size of marine algae can vary from very tiny to larger size. However, they are categorized under the group of multicellular algae $[3,4]$

\footnotetext{
* Correspondence: natanam@ump.edu.my

${ }^{1}$ Algae Culture Collection Center \& Laboratory, Faculty of Industrial Sciences \& Technology, Universiti Malaysia Pahang, Lebuhraya Tun Razak, Kuantan, 26300, Gambang, Pahang, Malaysia

${ }^{2}$ Earth Resources and Sustainability Centre (ERAS), Universiti Malaysia Pahang, Lebuhraya Tun Razak, Kuantan, 26300, Gambang, Pahang, Malaysia Full list of author information is available at the end of the article
}

Over the past few decades, nanoparticles in their nanometric scale $(1-100 \mathrm{~nm})$ have elicited much interest besides structurally exhibit extensively improved physical, chemical, and biological properties, features, and functionality. Nanomaterials exhibit unique, superior, and essential properties and have attracted much attention for their distinct characteristics that are not displayed in conventional macroscopic materials. Their uniqueness arises specifically due to their higher surface to volume ratio $[5,6]$. They represent the involvement of controlling and manipulating matter at their atomic scale in the development of novel devices that can be used in various physical, biological, biomedical, and pharmaceutical applications [7]. In recent research years, 
nanophasic and nanostructured materials proved to have high potential to achieve specific processes and selectivity, particularly in biological and pharmaceutical applications which attracts a great impact of interest [8].

Over the past centuries, silver has been used as a safe inorganic antibacterial agent which is non-toxic and well known in capable of killing about 650 types of diseases causing microorganisms [9]. Silver has been described as being oligodynamic because of its ability to exert a significant potential for a wide range of biological applications such as antifungal agent and antibacterial agents for antibiotic-resistant bacteria, preventing infections, healing wounds, and anti-inflammatory even at minute concentration. Silver ions $\left(\mathrm{Ag}^{+}\right)$, are engaged in the formulation of dental resin composites, bone cement, ion exchange fibers and coatings for medical devices since its being an antibacterial component [4]. Recently, studies conducted have shown that silver nanoparticles exhibit strong inhibition and serve as a protective barrier for most of the microorganism, for example, grampositive bacteria, gram-negative bacteria, drug-resistant bacteria, viruses, fungus, and even some of the pathogens $[6,10]$

Studies have shown that the silver nanoparticles which can be synthesized using algae are cost-effective and environmentally friendly as they do not require toxic chemicals in the process [11]. The availability of marine algae throughout the year and easy accessibility to harvest them encourages the researchers' interest on marine algae-mediated biosynthesis of silver nanoparticles. A detection of silver nanoparticles via characterization determines whether the silver nanoparticles are actually synthesized or not. Characterization of the nanoparticles normally examines the size, shape, and quantity of nanoparticles produced. There are different measurement techniques imposed for this purpose including UV-Vis spectroscopy, atomic force microscopy (AFM), scanning electron microscopy (SEM), absorbance spectroscopy, and dynamic light scattering (DLS).

The objectives of this present study are biosynthesis of silver nanoparticles using an aqueous extract of Padina sp. marine alga, characterization of biosynthesized silver nanoparticles to evaluate the antibacterial activity of silver nanoparticles, and identification of bioactive compounds in the marine alga using gas chromatography and mass spectrometry (GC-MS).

\section{Methods}

\subsection{Marine algae sample collection}

Marine algae were collected by handpicking method as depicted from Mersing, Johor at Peninsular Malaysia. Brown marine algae were found attached on the surface of rocks along the beach. The marine algae were collected inside a polyethylene bag. The marine alga samples which collected in large amount were repeatedly surface-sterilized using sterile seawater followed by distilled water to get rid of extraneous materials such as sand, dust, and salt content as well [12].

\subsection{Identification of marine algae}

Then, the marine algae sample was identified by referring to macroalgae standard manual [13] or preferred marine algae-A Field Manual of National Institute of Oceanography (2004) to determine which species it belongs to. The marine alga was identified as belonging to the class Phaeophyceae, order Dictyotales, family Dictyotaceae, and genus Padina based on its morphological studies done. The marine alga was posed as striped, yellowish-brown, fan-shaped, lobbed, 2-8-celled thick marked with a concentric row of hairs also with cylindrical axis bearing leaves and vesicles. It had "ear-like" blades with enrolled apical margin. It also had thalli which were irregularly cleft into narrow lobes as shown in Fig. 1. Other than that, morphological verification is not a complete and enough information to identify the species of marine algae. In order to identify the species of marine algae sample, the anatomic studies should be carried out. Therefore, this research only covered up until the identification of genus of marine alga sample collected. After all this, the cleaned samples will be preserved in a clean zip-lock polyethylene bags. The bags will be stored under refrigeration at $8^{\circ} \mathrm{C}$ for further process [14].

\subsection{Preparation of aqueous marine alga extract}

The Padina sp. marine alga extract was prepared by the intracellular extraction methodology previously studied by Kannan et al. and Kumar et al. [8, 12] with slight modifications. The preserved Padina sp. samples were again cleaned using distilled water in order to remove the epiphytes and other contamination [15]. The preserved Padina sp. samples were shade-dried for 2 weeks to remove the moisture content completely. Eventually, after 2 weeks, the Padina sp. was turned into olive green upon drying and then it was oven-dried at $50{ }^{\circ} \mathrm{C}$ for 15 $20 \mathrm{~min}$ in order to prevent any fungal contamination in the sample. Then, the dried Padina sp. was weighed using analytical balance until a constant dry weight of $120 \mathrm{~g}$ was recorded. The dried Padina sp. was groundpowdered using a mixer grinder. Then, a total of 105.00 $\mathrm{g}$ of powered Padina sp. was obtained and kept in an air-tight container. Later, aqueous marine alga extract was prepared by dissolving $30 \mathrm{~g}$ of powdered Padina sp. marine alga in $300 \mathrm{ml}$ of sterile distilled water in a 1:10 ratio. The extract was heated at $60^{\circ} \mathrm{C}$ for $20 \mathrm{~min}$ then filtered using a vacuum filter pump layered by Whatman no.1 filter paper [12]. The aqueous extract of Padina sp. was then refrigerated at $4{ }^{\circ} \mathrm{C}$ for further analysis. 


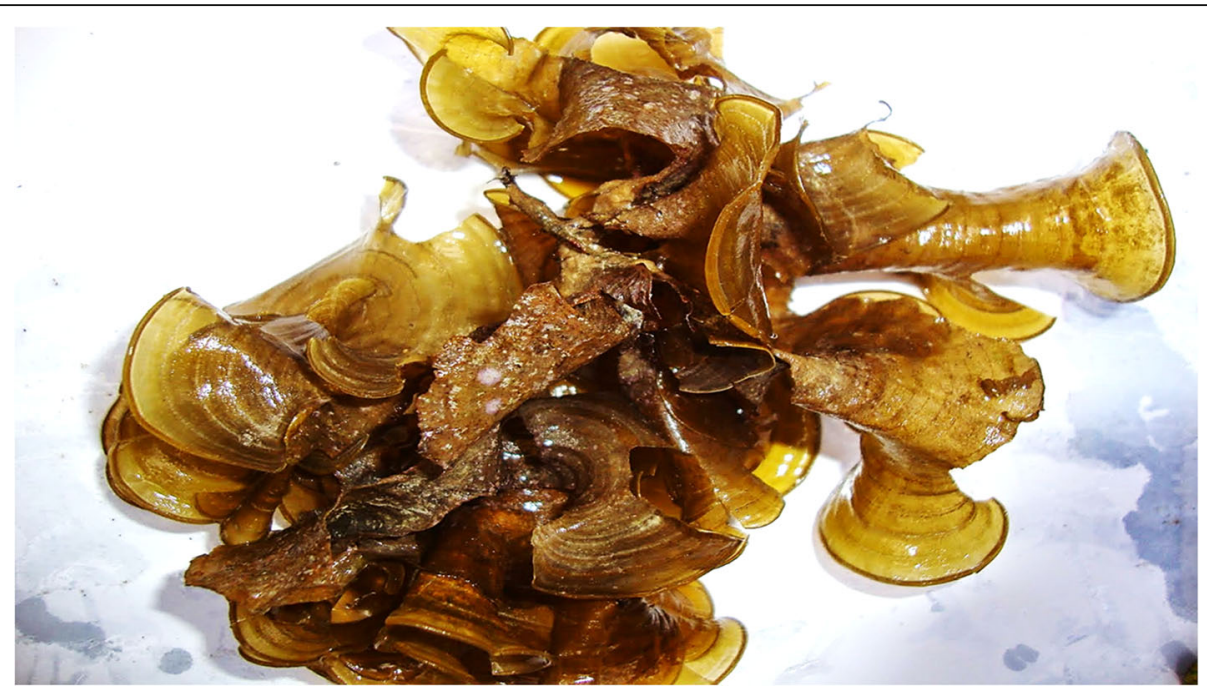

Fig. 1 The seaweed sample collected at "Pantai Pasir Lanun"

\subsection{Synthesis of silver $(\mathrm{Ag})$ nanoparticles}

In the typical synthesis of silver nanoparticles, $20 \mathrm{ml}$ of the aqueous extract of Padina sp. was added to $180 \mathrm{ml}$ of $0.01 \mathrm{M}$ of aqueous silver nitrate $\left(\mathrm{AgNO}_{3}\right.$, Sigma $\mathrm{Al}$ drich) solution which was prepared using deionized water in $250 \mathrm{ml}$ conical flask. The synthesis medium was gradually and indirectly heated up to $60^{\circ} \mathrm{C}$ and stirred using a magnetic stirrer for $48 \mathrm{~h}$ in order to ensure a complete reduction of metal ion to occur $[12,14]$. The synthesis medium carried out in triplicate and the setup of the experiment done. Besides that, the setup was carried out in dark condition so that to minimize the photoactivation of silver nitrate. A control setup was also maintained without the aqueous marine alga extract [8]. The change in color from yellowish-brown to a concentrated dark brown color solution was observed as a visible confirmation for the formation of silver nanoparticles before the sample was subjected to further characterization process.

After $48 \mathrm{~h}$ completed, the synthesis medium was centrifuged at $8000 \mathrm{rpm}$ at $30^{\circ} \mathrm{C}$ for $30 \mathrm{~min}$. The silver nanoparticles which deposited at the bottom forming a pellet upon centrifugation and the supernatant were discarded. The silver nanoparticle pellet was oven-dried at $50{ }^{\circ} \mathrm{C}$ for $5 \mathrm{~h}$ in order to remove the moisture content. Then, the dried silver nanoparticle was pressed into powdered form using pestle aluminum foil. At the end of the synthesis process, about $510.0 \mathrm{mg}$ of silver nanoparticle was managed to be synthesized.

\subsection{Characterization of silver nanoparticles synthesized}

The UV-Vis spectrophotometer (PerkinElmer -Lamda25, USA) was used to measure the wavelength between 300 and $800 \mathrm{~nm}$ to monitor the formation of silver nanoparticles using marine alga extract with regular intervals of $0 \mathrm{~min}$ (before heating), $15 \mathrm{~min}, 30 \mathrm{~min}, 45$ min, $1 \mathrm{~h}, 2 \mathrm{~h}, 4 \mathrm{~h}, 8 \mathrm{~h}, 12 \mathrm{~h}, 24 \mathrm{~h}, 36 \mathrm{~h}$, and then followed by $48 \mathrm{~h}$. Dilutions of samples were made if the sample was too concentrated. The UV-visible reading was recorded and then analyzed using the Origin Pro or Microsoft Excel analysis tool. Fourier transform infrared spectroscopy (FT-IR- Perkin-Elmer, USA) of marine alga extract and synthesized AgNPs and $0.01 \mathrm{M}$ of silver nitrate solution were analyzed in the range between 4000 $\mathrm{cm}^{-1}$ and $400 \mathrm{~cm}^{-1}$. The size and morphology of the nanoparticles using scanning electron microscopy (SEM) (ZEISS EVO 50 Germany) and field emission scanning electron microscopy (FESEM) equipped with energydispersive X-ray spectroscopy (JSM-7500F, JEOL, Japan). A minute drop of nanoparticle powder was cast on to a carbon-coated copper grid and subsequently transferred to the microscope. The high-resolution images of silver nanoparticles were recorded and the morphology of AgNPs was further studied. Energy-dispersive X-ray spectrophotometer (FE Detector, $5.0 \mathrm{kV}$, high vacuum 5 $\times$ 10-3 Pa) working with EDX Link 300 OXFORD (Detector $\mathrm{Si}(\mathrm{Li}), 30 \mathrm{kV}$, low vacuum $10 \mathrm{~Pa}$, resolution $20 \mathrm{keV}$ ) were used to record EDX spectrum.

\subsection{Antibacterial activity of AgNPs}

Antibacterial activity of the synthesized AgNPs was evaluated against two gram-positive bacteria, Staphylococcus aureus and Bacillus subtilis, and three gram-negative bacteria, Pseudomonas aeruginosa, Salmonella typhi, and Escherichia coli, with four different concentration of silver nanoparticles biosynthesized using disc diffusion method [16]. The 5-mm discs with four different concentrations of biosynthesized silver nanoparticles $(0.25$ $\mathrm{mg} / \mathrm{ml}, 0.50 \mathrm{mg} / \mathrm{ml}, 0.75 \mathrm{mg} / \mathrm{ml}$, and $1.00 \mathrm{mg} / \mathrm{ml}$ ) were tested against selected pathogenic bacteria with $0.01 \mathrm{M}$ 
of silver nitrate solution and $25 \mu \mathrm{g}$ ampicillin disc as positive control while deionized water as negative control. Aqueous dispersions of silver nanoparticles of desired concentrations $(0.25 \mathrm{mg} / \mathrm{ml}, 0.50 \mathrm{mg} / \mathrm{ml}, 0.75 \mathrm{mg} /$ $\mathrm{ml}$, and $1.00 \mathrm{mg} / \mathrm{ml}$ ) were made. Bacterial suspension was prepared by a single colony sub-cultured overnight in nutrient broth and by the turbidity was adjusting to 0.5 McFarland standards [17].

Then the Mueller-Hinton agar was used to grow bacterial cultures and $0.1 \mathrm{ml}$ of the bacterial suspensions was spread on the plate using the sterile cotton swab [18]. The plates then were incubated at $37^{\circ} \mathrm{C}$ for $24 \mathrm{~h}$ in a bacteriological incubator and the zone of inhibition was measured by performing the experiment in triplicate (Fig. 2).

\subsection{Identification of bioactive compounds in freeze-dried marine algae extract using GC-MS analysis}

The aqueous solution of Padina sp. extract $(10 \mathrm{~g} / 100 \mathrm{ml})$ was stored in a freezer under $-80^{\circ} \mathrm{C}$ for 2 days. Then, the solidified extract was freeze-dried for 3 days and the powdered extract was analyzed using GC-MS analysis performed with DB-5 column $(30 \mathrm{~m} \times 250 \mu \mathrm{m} \times$ $0.25 \mu \mathrm{m})$. Helium gas $(99.999 \%)$ was used as the carrier gas at a constant flow rate of $1 \mathrm{ml} / \mathrm{min}$ with a split ratio of $1: 50$. The inlet temperature was $250^{\circ} \mathrm{C}$ and the oven temperature was programmed from initial with $60^{\circ} \mathrm{C}$, hold for $1 \mathrm{~min}$ ramp, with an increase of $10^{\circ} \mathrm{C} / \mathrm{min}$, to $301{ }^{\circ} \mathrm{C}$, and then hold for $5 \mathrm{~min}$. The detector temperature was $230^{\circ} \mathrm{C}$ and the transfer line temperature was $310^{\circ} \mathrm{C}$. The bioactive compounds present in the freeze-dried Padina sp. marine alga extract (powder) were identified by comparing the retention time of the chromatographic peaks with those of authentic compounds under the same conditions [19].

\section{Result}

\subsection{Characterization of silver nanoparticles}

The synthesis of AgNPs was performed with $0.01 \mathrm{M}$ of silver nitrate solution with marine alga extract in Erlenmeyer flask in the ratio of 1:10, respectively, at the initial time point of the synthesis reaction, and $0.01 \mathrm{M}$ of silver nitrate solution without marine alga extract was maintained as a control. The solution remains colorless and showed no color change even after $48 \mathrm{~h}$ upon heating as shown in Fig. 3a. The reduction of silver nitrate $\left(\mathrm{AgNO}_{3}\right)$ was visually confirmed by the change of color from yellowish-brown to reddish-brown after $30 \mathrm{~min}$ of reaction as shown in Fig. 3b. The color of the marine alga extract became turbid after the addition of aqueous $\mathrm{AgNO}_{3}$ solution signifying the initiation of the reaction. The intensity of brown color increased in direct

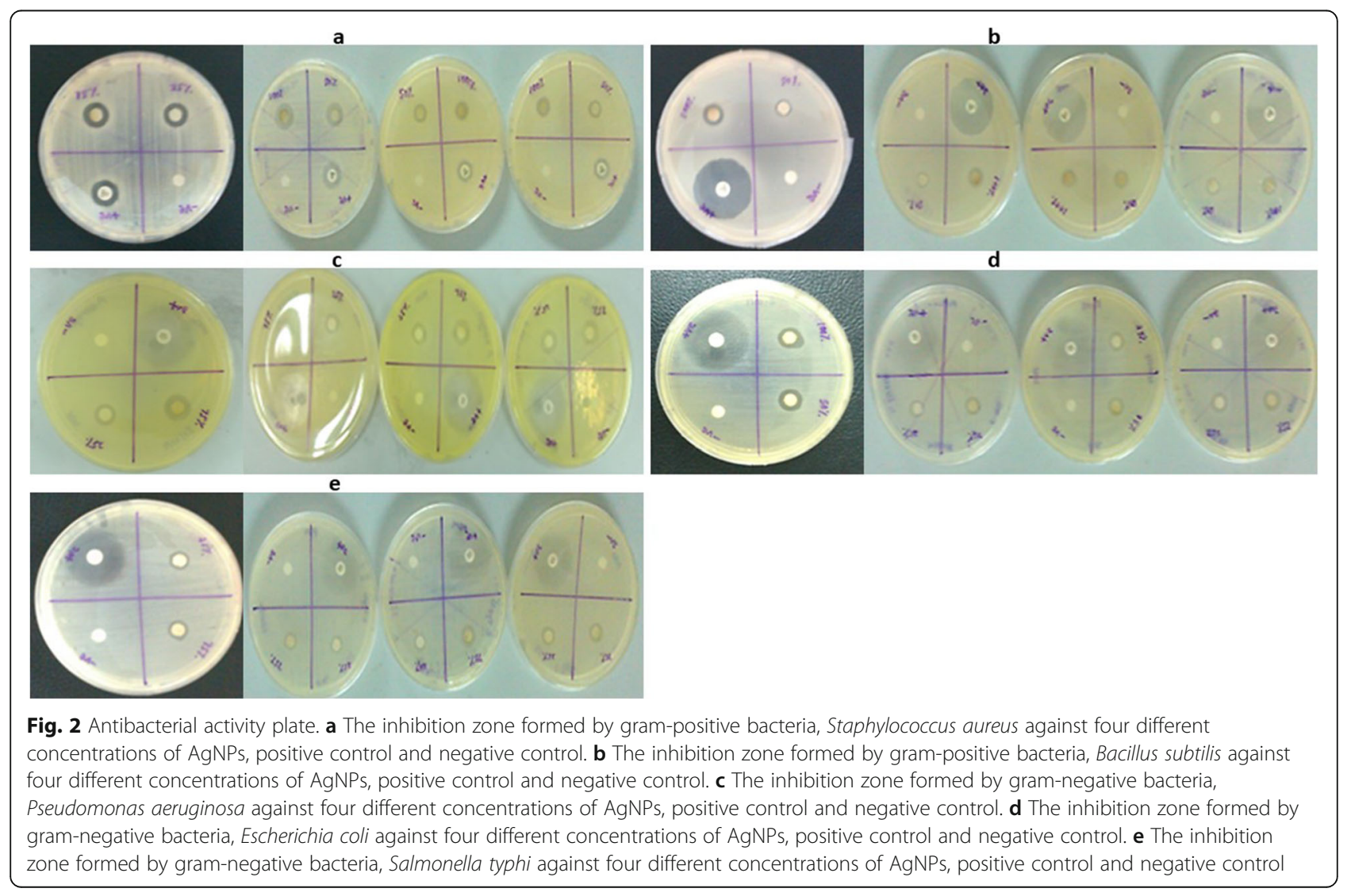




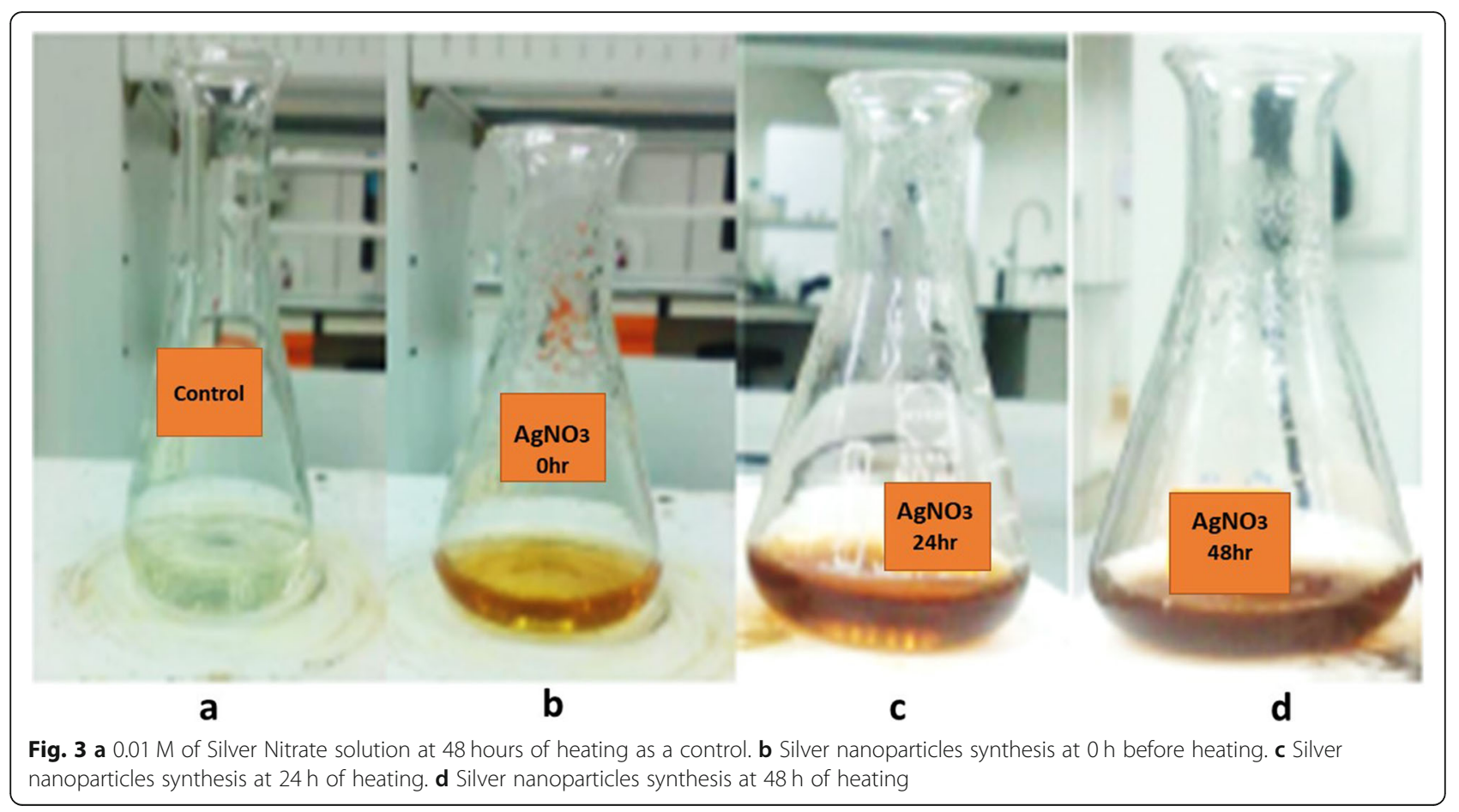

proportion to the heating period of $24 \mathrm{~h}$ followed by 48 $\mathrm{h}$ as shown in Fig. 3c, d.

\subsection{Ultraviolet-visible spectroscopy (UV-Vis) analysis}

The characterization of silver nanoparticles based on surface plasmon resonance (SPR) vibration observed at $445 \mathrm{~nm}$ confirmed the synthesis of AgNPs using marine alga extract. The silver SPR band occurred at $420 \mathrm{~nm}$ to $445 \mathrm{~nm}$ showed a steady increase in absorbance until 48 $\mathrm{h}$ as shown in Fig. 4. The broadening of peak signified that the particles are polydispersed. Furthermore, the peak intensity increased as the samples are treated for a longer time.

\subsection{Fourier transform infrared spectroscopy (FTIR) analysis}

FTIR analysis was carried out to identify the presence of functional groups in the aqueous extract of marine alga Padina sp. (Table 1) According to Fig. 5a, major transmission peaks were observed at $3350.07 \mathrm{~cm}^{-1}, 1637.74$ $\mathrm{cm}^{-1}$, and $1106.90 \mathrm{~cm}^{-1}$ [20] for Padina sp. extract represents $\mathrm{O}-\mathrm{H}$ and $\mathrm{C}=\mathrm{O}$ stretching for hydroxyl group and carboxylic acid and $3350.24 \mathrm{~cm}^{-1}, 1635.83$

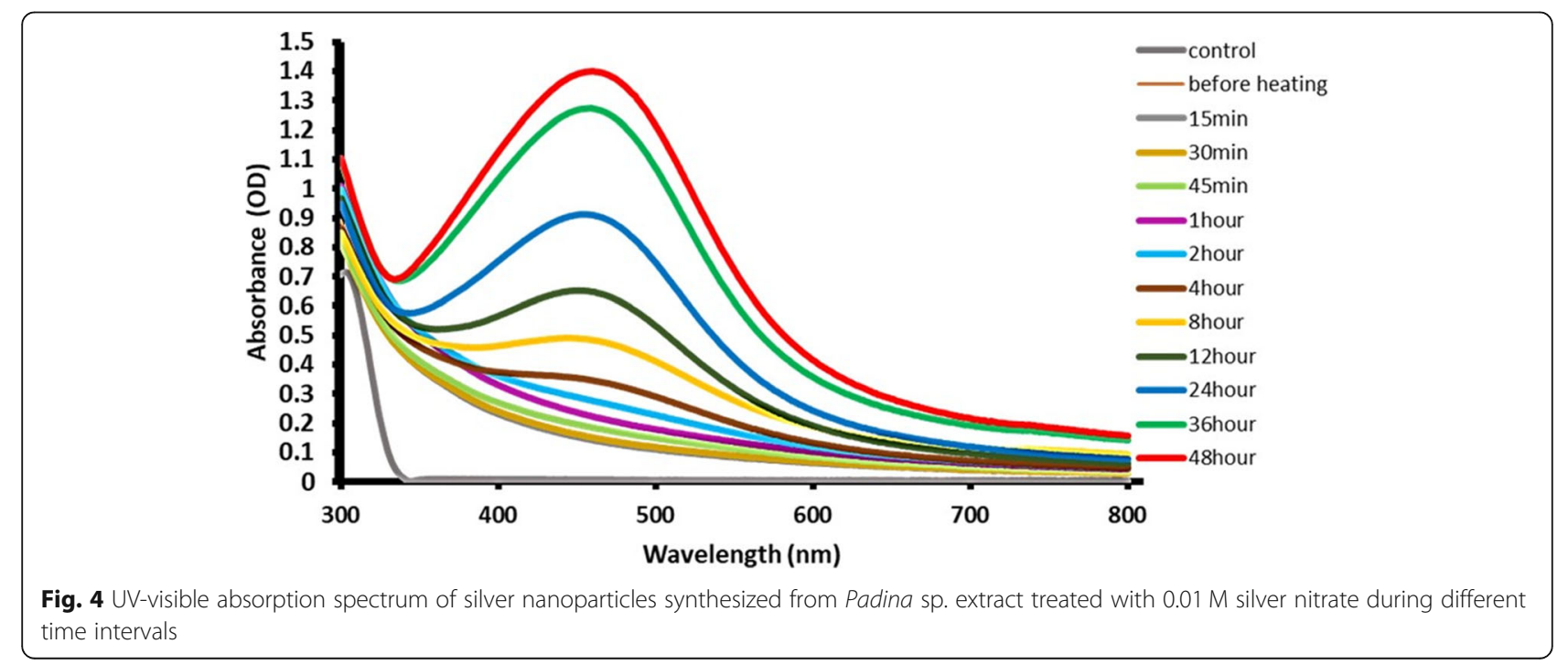


Table $1 \mathrm{FTIR}$ analysis of Padina sp. aqueous extract, $0.01 \mathrm{M}$ of silver nitrate $\left(\mathrm{AgNO}_{3}\right)$ solution, and silver nanoparticles synthesized by the reduction of $0.01 \mathrm{M}$ silver nitrate with the Padina sp. aqueous extract

\begin{tabular}{|c|c|c|c|c|c|c|c|c|}
\hline \multicolumn{3}{|c|}{ Padina sp. aqueous extract } & \multicolumn{3}{|c|}{$0.01 \mathrm{M}$ of silver nitrate $\left(\mathrm{AgNO}_{3}\right)$ solution } & \multicolumn{3}{|c|}{ Silver nanoparticles (AgNPs) synthesized } \\
\hline $\begin{array}{l}\text { Frequency } \\
\left(\mathrm{cm}^{-1}\right)\end{array}$ & Bond/stretching & Functional groups & $\begin{array}{l}\text { Frequency } \\
\left(\mathrm{cm}^{-1}\right)\end{array}$ & Bond/stretching & Functional groups & $\begin{array}{l}\text { Frequency } \\
\left(\mathrm{cm}^{-1}\right)\end{array}$ & Bond/stretching & $\begin{array}{l}\text { Functional } \\
\text { groups }\end{array}$ \\
\hline 3350.07 & $\begin{array}{l}\mathrm{N}-\mathrm{H} \text { stretch, } \mathrm{O}-\mathrm{H} \\
\text { stretch, } \mathrm{H} \text {-bonded }\end{array}$ & $\begin{array}{l}1^{\circ}, 2^{\circ} \text { amines, } \\
\text { amides, carboxyl, } \\
\text { phenols }\end{array}$ & 3350.24 & $\begin{array}{l}\mathrm{N}-\mathrm{H} \text { stretch, } \mathrm{O}-\mathrm{H} \\
\text { stretch, } \mathrm{H} \text {-bonded }\end{array}$ & $\begin{array}{l}1^{\circ}, 2^{\circ} \text { amines, } \\
\text { amides, alcohols, } \\
\text { phenols }\end{array}$ & 3422.00 & $\begin{array}{l}\mathrm{O}-\mathrm{H} \text { stretch, } \mathrm{H}- \\
\text { bonded }\end{array}$ & $\begin{array}{l}\text { Alcohols, } \\
\text { phenols }\end{array}$ \\
\hline 2123.39 & $-C \equiv C-$ stretch & alkynes & 2124.36 & $-C \equiv C-$ stretch & alkynes & 2921.02 & $\mathrm{C}-\mathrm{H}$ stretch & alkanes \\
\hline 1637.74 & $\mathrm{~N}-\mathrm{H}$ bend & $1^{\circ}$ amines & 1635.83 & $\mathrm{~N}-\mathrm{H}$ bend & $1^{\circ}$ amines & 1610.46 & $\mathrm{~N}-\mathrm{H}$ bend & $1^{\circ}$ amines \\
\hline 1329.82 & $\begin{array}{l}\mathrm{N}-\mathrm{O} \text { symmetric } \\
\text { stretch }\end{array}$ & Nitro compounds & 1337.47 & $\begin{array}{l}\mathrm{N}-\mathrm{O} \text { symmetric } \\
\text { stretch }\end{array}$ & nitro compounds & 1384.27 & $\begin{array}{l}-\mathrm{NO}_{2} \text { (aliphatic) } \\
\text { or } \mathrm{C}-\mathrm{H} \text { (plane } \\
\text { bend) }\end{array}$ & $\begin{array}{l}\text { nitro groups } \\
\text { or alkenes }\end{array}$ \\
\hline 1106.90 & $\mathrm{C}-\mathrm{N}$ stretch & aliphatic amines & 1181.13 & $\mathrm{C}-\mathrm{H}$ wag $\left(-\mathrm{CH}_{2} \mathrm{X}\right)$ & alkyl halides & 1023.91 & $\mathrm{C}-\mathrm{N}$ stretch & $\begin{array}{l}\text { aliphatic } \\
\text { amines }\end{array}$ \\
\hline
\end{tabular}

$\mathrm{cm}^{-1}$, and $1337.47 \mathrm{~cm}^{-1}$ [21] for $0.01 \mathrm{M}$ silver nitrate solution, respectively. The FTIR spectra band corresponding to $3350.07 \mathrm{~cm}^{-1}$ is due to $\mathrm{N}-\mathrm{H}$ stretching vibrations of peptide linkages and hydroxyl stretch vibrations of carboxylic acid groups demonstrating the presence of polyphenols [12] in aqueous Padina sp. extract. Likewise, another band observed at 1637.74 $\mathrm{cm}^{-1}$ [22] is assigned to the vibration of $\mathrm{N}-\mathrm{H}$ primary amine group and it may well arise due to carbonyl stretch in polyphenols.

\subsection{Scanning electron microscopy analysis of silver nanoparticles}

The SEM image in Fig. 6 showing the high-density silver nanoparticles synthesized by treating Padina sp. extract further confirmed the development of silver nanostructures. The silver nanoparticles seem to be distributed with an average mean size $33.75 \mathrm{~nm}$. The nanoparticles further subjected to FESEM for more high-resolution analysis and clearer images.

\subsection{Field emission scanning electron microscopy analysis of silver nanoparticles}

A field emission scanning electron microscope (FESEM) was employed to analyze the morphology structure, size, shape, and distribution of the nanoparticles formed. The FESEM produces clearer images with higher quality and resolution about 3 to 6 times better than conventional SEM [23]. From Fig. 6, it is evident that the silver nanoparticles were coalesced to nano-clusters.

When the reaction mixtures of the synthesis medium of silver nanoparticles were indirectly heated for $48 \mathrm{~h}$, most of the nanoparticles tend to be aggregated as shown in Fig. 7 . When silver nanoparticles aggregate, the metal particles become electronically coupled and this coupled system has a different surface plasmon resonance than the individual particles. For the case of a multi-nanoparticle aggregate, the SPR will be shifted to a longer wavelength than the resonance of an individual nanoparticle, and aggregation is observable as an intensity increase in the infrared region of the UV-visible spectrum [24]. Furthermore, the drying factor of silver nanoparticles can be one of the factors influencing the rate of aggregation of silver nanoparticles synthesized [25].

\subsection{Energy-dispersive X-ray spectrum analysis}

The presence of elements and atomic proportions of marine algae-mediated AgNPs was determined using an energydispersive X-ray spectrometer (Table 2). The analysis through FESEM-EDX spectrum recorded showing a sharp peak between $2.8 \mathrm{keV}$ and $8.0 \mathrm{keV}$ Fig. 8 confirmed the presence of an elemental silver signal of the silver nanoparticles [26].

\subsection{Antibacterial activity by disc diffusion assay 3.7.1 Antibacterial activity of silver nanoparticles against clinical pathogens}

The antibacterial activity of marine algae extract-mediated biosynthesized silver nanoparticle was evaluated against pathogenic bacteria such as two gram-positive bacteria, Staphylococcus aureus and Bacillus subtilis, and three gram-negative bacteria, Pseudomonas aeruginosa, Escherichia coli, and Salmonella typhi, by disc diffusion assay as shown in Fig. 2a-e. Among the two gram-positive bacteria, silver nanoparticles against Staphylococcus aureus showed the highest zone of clearance about $15.17 \mathrm{~mm} \pm 0.58$ as shown in Table 3, followed by $12.67 \pm 0.76 \mathrm{~mm}$ clear inhibition zone for Bacillus subtilis (Fig. 9). On the other hand, gram-negative bacteria Pseudomonas showed the highest zone of clearance about $13.33 \pm 0.76 \mathrm{~mm}$, followed by $12.67 \pm 0.58 \mathrm{~mm}$ for Escherichia coli.

\subsubsection{Identification of bioactive compounds in freeze-dried extract of Padina sp. marine alga using GC-MS analysis}

A high-resolution mass spectrum equipped with a data system in combination with gas chromatography (Agilent Tech 5975 C) was used for the chemical analysis of marine alga Padina sp. The freeze-dried Padina sp. extract powder was subjected to GC-MS analysis to identify the 


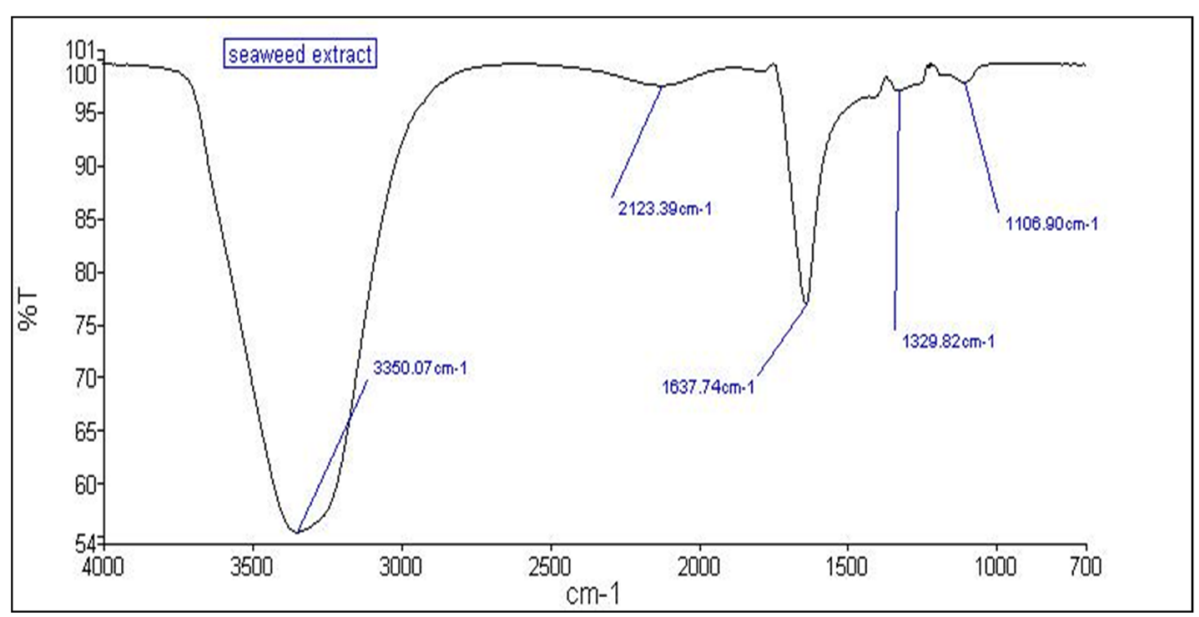

a

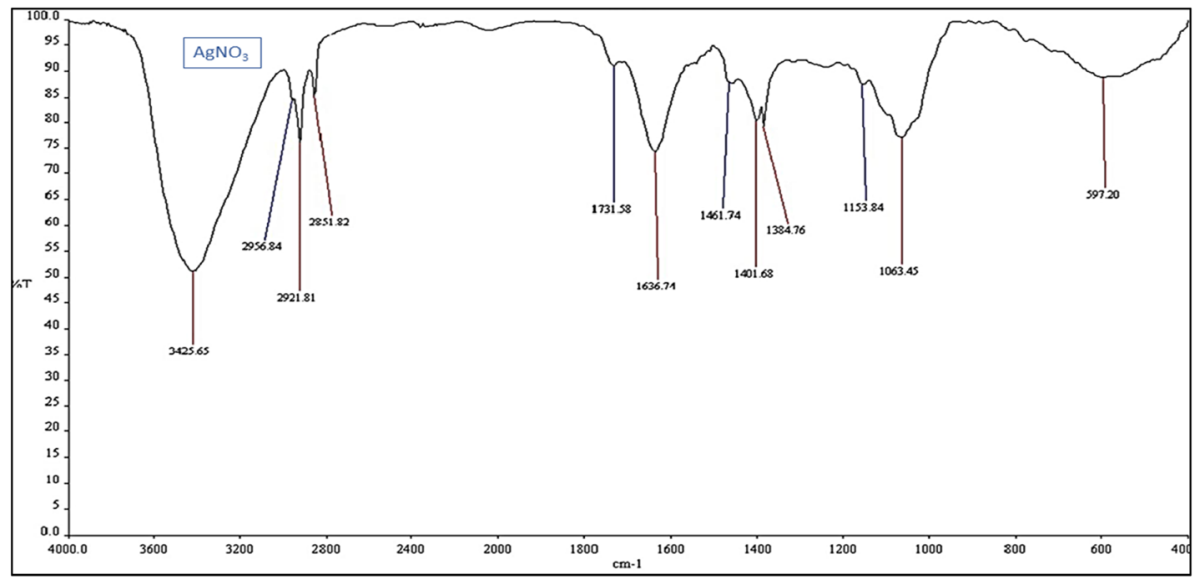

b

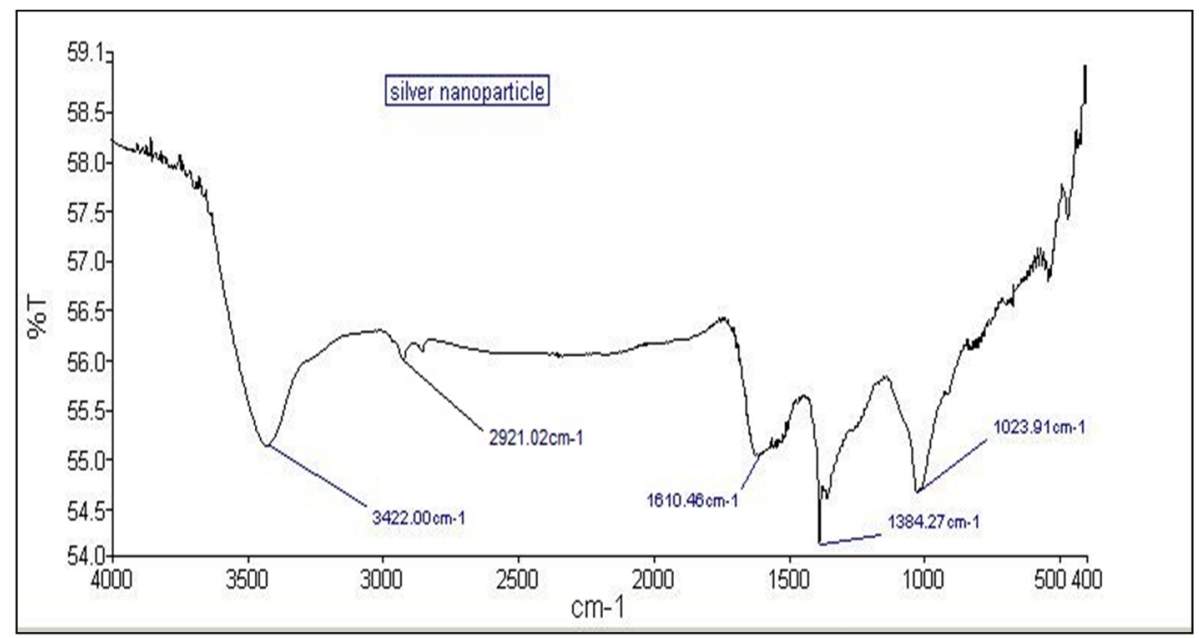

c

Fig. 5 a FTIR spectra of Padina sp. aqueous extract. b FTIR spectra of aqueous $0.01 \mathrm{M}$ of silver nitrate $\left(\mathrm{AgNO}_{3}\right)$ solution. c FTIR spectra of silver nanoparticles (AgNPs) synthesized by the reduction of $0.01 \mathrm{M}$ silver nitrate with the Padina sp. aqueous extract 


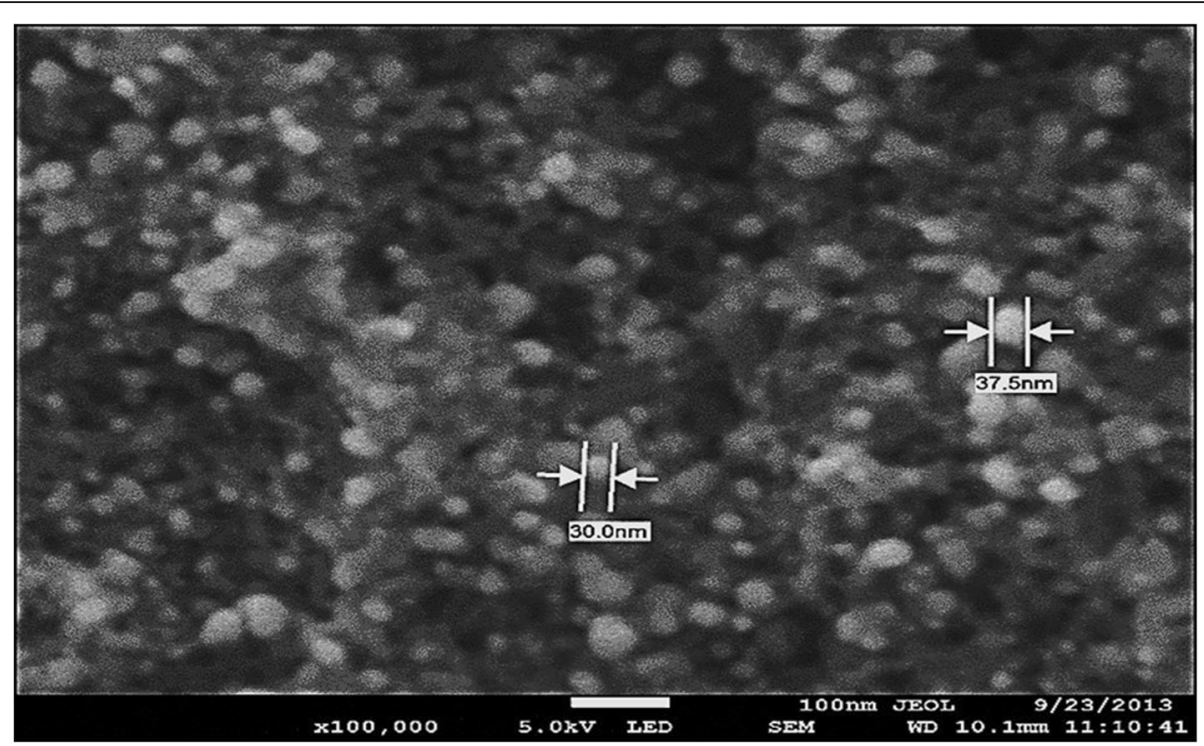

Fig. 6 SEM image of silver nanoparticles (AgNPs) synthesized by treating Padina sp. extract with $0.01 \mathrm{M}$ of silver nitrate solution

bioactive compounds' presence in the extract. The compound name, molecular weight, and molecular formula of the components of the test materials were ascertained as shown in Table 4. The freeze-dried aqueous Padina sp. extract on the basis of spectral data by GC-MS analysis was found to be a mixture of volatile compounds. In the present study, a total of 22 peaks were observed and 25 bioactive compounds have been identified from freezedried aqueous Padina sp. Among the 22 compounds identified, only 9 compounds with purity or quality of more than or equal to $80 \%$ were tabulated as shown in Table 4.
The GC-MS analysis of the aqueous extract revealed that the main phyto-constituent or phytochemical was cyclononasiloxane as shown in Fig. 10 with peak area of $17.94 \%(\mathrm{Rt}=17.814 \mathrm{~min})$ followed by $\mathrm{n}$-hexadecanoic acid, octadecanoic acid with peak area of $7.03 \%$ (Rt $=$ $18.712 \mathrm{~min}$ ), and then cycloheptasiloxane with a peak area of $3.24 \%$ ( Rt $=14.089 \mathrm{~min})$. On the other hand, there are compounds such as cyclodecasiloxane with $23.66 \%$ at $\mathrm{Rt}=19.359 \mathrm{~min}$; benzoic acid; 2,4-bis [(trimethylsilyl)oxy]-, trimethylsilyl ester with $11.12 \%$ at $\mathrm{Rt}=$ $16.092 \mathrm{~min}$; and also hydrazine, 1,1-dimethyl with $4.41 \%$

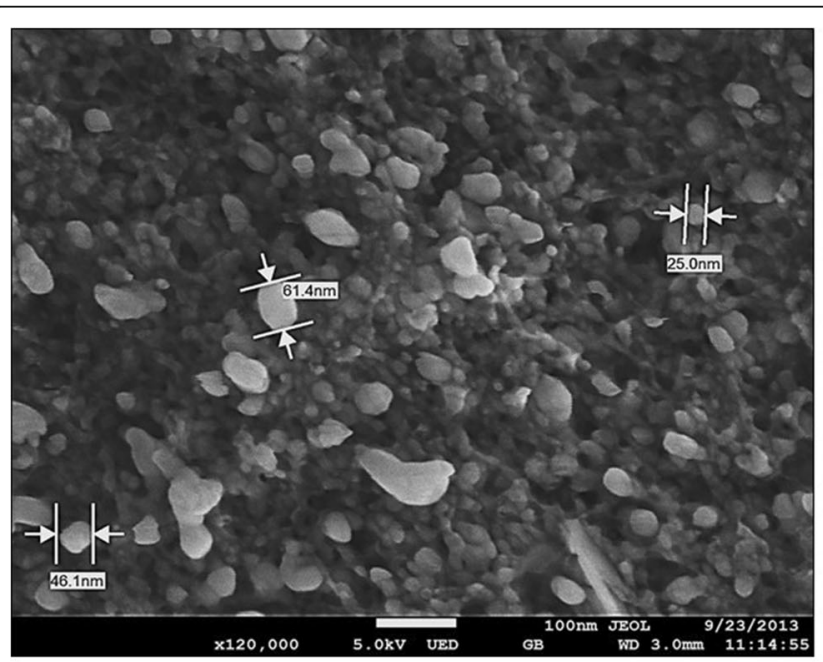

a

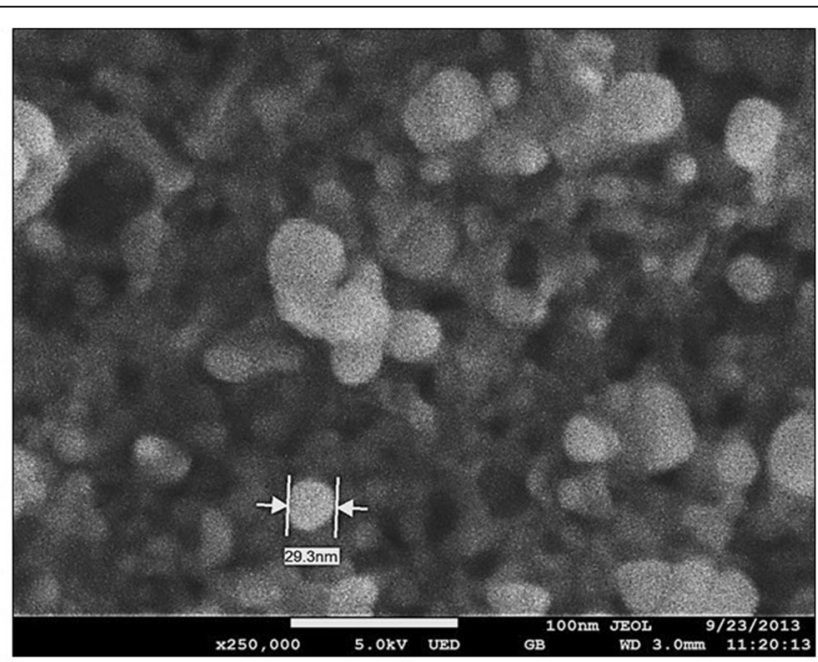

b

Fig. 7 FESEM images of silver nanoparticles (AgNPs) synthesized by the reaction of Padina sp. extract with $0.01 \mathrm{M}$ of silver nitrate $\left(\mathrm{AgNO}_{3}\right)$ solution 
Table 2 The relative weight and atomic proportions of each element present in the silver nanoparticles synthesized

\begin{tabular}{lll}
\hline Element & Wt\% & At\% \\
\hline C K & 1.35 & 14.02 \\
O K & 3.27 & 25.51 \\
Al K & 0.49 & 0.21 \\
Si K & 0.65 & 1.26 \\
Cl K & 9.04 & 10.66 \\
Ag L & 85.20 & 48.34 \\
Total & 100.00 & \\
\hline
\end{tabular}

at $\mathrm{Rt}=2.697 \mathrm{~min}$, respectively, in an abundant amount, but their purity of recovery is lesser than $80 \%$.

\section{Discussion}

\subsection{Characterization of silver nanoparticles}

The result obtained ultimately similar to the work done by Shivaraj [27] indicated the formation of AgNPs by reduction of the aqueous $\mathrm{Ag}^{+}$during the exposure to the aqueous extract of Padina tetrastomatica showed reddish-brown color upon $72 \mathrm{~h}$ of incubation period. It is well known that AgNPs exhibits reddish-brown in water [28] due to the excitation of surface plasmon resonance (SPR) effect of silver metal nanoparticles. It indicates that silver nanoparticles were formed by the reduction of $\mathrm{Ag}^{+}$into $\mathrm{Ag}^{0}$ upon the addition of marine alga extract to the solution of $0.01 \mathrm{M}$ of $\mathrm{AgNO}_{3}$ solution [14]. Particularly, even after $48 \mathrm{~h}$, there is no remarkable deepening of color indicating the saturation of reaction. This indicates that the particles might be well dispersed throughout the synthesis medium with mild agglomeration [18].

\subsection{Ultraviolet-visible spectroscopy (UV-Vis) analysis}

The frequency and width of the surface plasmon absorption depend on the size and shape of the metal nanoparticles as well as on the dielectric constant of the metal itself and the surrounding medium [29]. Similar SPR vibrations have been observed in the previous report using marine alga Urospora sp. for the biosynthesis of AgNPs [14].

\subsection{Fourier transform infrared spectroscopy (FTIR) analysis}

The observed peaks were more assigned the characteristic of terpenoids which was similar to the previous study done by Sahayaraj et al. [6] using marine alga Padina pavonica. On the other hand, the shift of band from $1106.90 \mathrm{~cm}^{-1}$ [12] is attributed to the binding of $\mathrm{C}-\mathrm{N}$ aliphatic amine group with nanoparticle reduction. Furthermore, as shown in Fig. 5b, the shift of band decreases at its intensity at $1181.13 \mathrm{~cm}^{-1}$ which attributed to the aldehyde groups shows the possibility that the terpenoids play a role in the reduction of metal ions by oxidation of aldehydic groups in the molecules to carboxylic acids [30]. The stretch between $2123.39 \mathrm{~cm}^{-1}$ and $2124.36 \mathrm{~cm}^{-1}$ [8] according to Table 1 typically formed by triple $\mathrm{C} \equiv \mathrm{C}$ bond in alkynes, and those vibrational bands might be derived from water-soluble

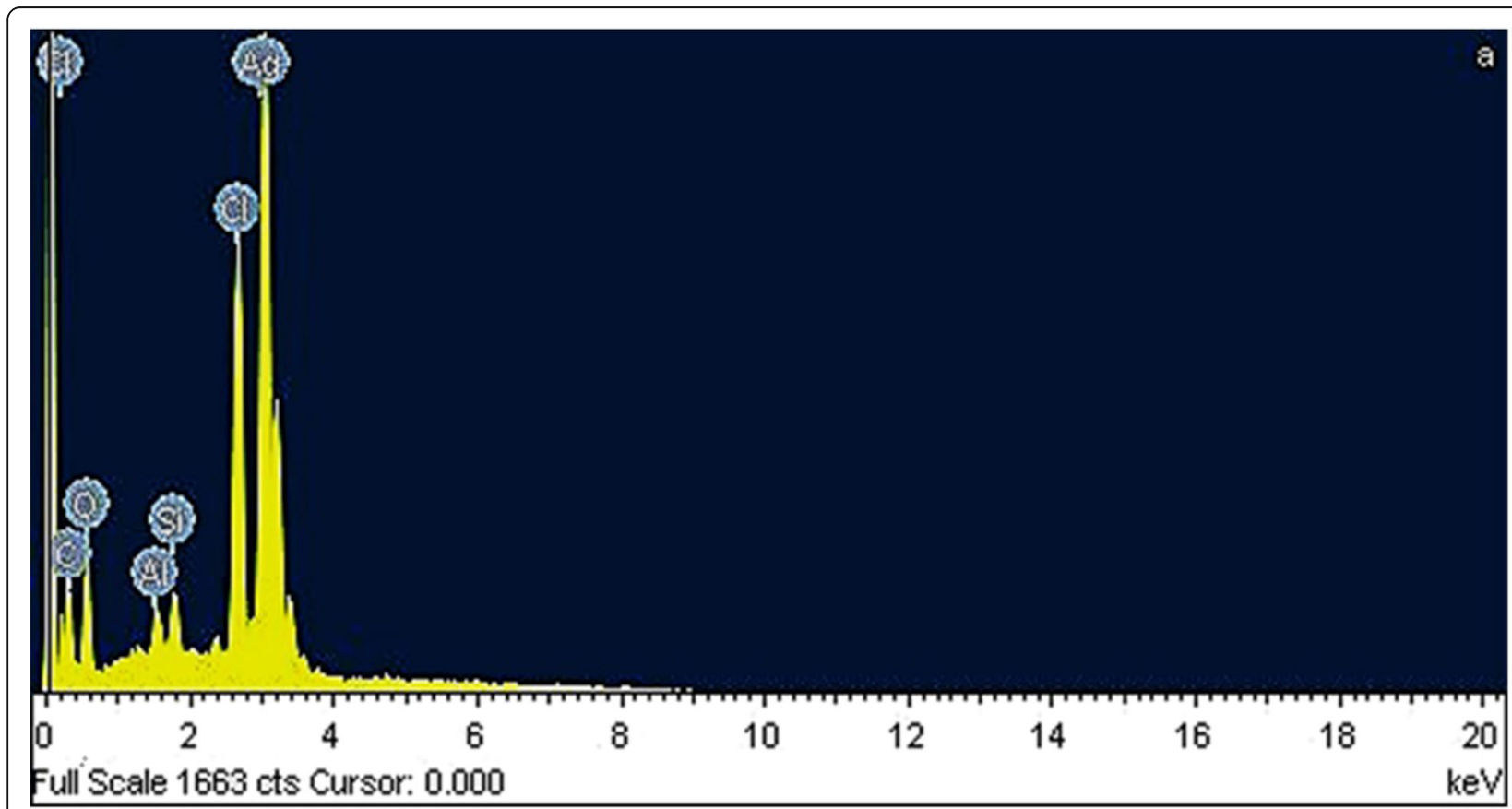

Fig. 8 EDX spectrum of silver nanoparticles synthesized 
Table 3 Summary of antibacterial activity of biosynthesized silver nanoparticles by Padina sp. against five pathogenic bacteria including gram-positive Staphylococcus aureus and Bacillus subtilis and gram-negative Pseudomonas aeruginosa, Escherichia coli, and Salmonella typhi with positive and negative control

\begin{tabular}{|c|c|c|c|c|c|}
\hline \multirow{2}{*}{$\begin{array}{l}\text { Concentration, mg/ } \\
\mathrm{ml}\end{array}$} & \multicolumn{2}{|l|}{ Gram-positive organism } & \multicolumn{3}{|l|}{ Gram-negative organism } \\
\hline & Staphylococcus aureus & Bacillus subtilis & Pseudomonas aeruginosa & Escherichia coli & Salmonella typhi \\
\hline 0.25 & $10.50 \pm 0.50$ & $7.00 \pm 0.50$ & $8.33 \pm 0.29$ & $7.50 \pm 0.50$ & $6.50 \pm 0.50$ \\
\hline 0.50 & $11.17 \pm 0.29$ & $8.17 \pm 0.29$ & $10.00 \pm 0.50$ & $9.17 \pm 0.29$ & $8.00 \pm 0.50$ \\
\hline 0.75 & $12.50 \pm 0.50$ & $10.67 \pm 0.58$ & $12.00 \pm 0.50$ & $11.17 \pm 0.29$ & $10.00 \pm 0.50$ \\
\hline 1.00 & $15.17 \pm 0.58$ & $12.67 \pm 0.76$ & $13.33 \pm 0.76$ & $12.67 \pm 0.58$ & $11.50 \pm 0.50$ \\
\hline Standard (ampicillin) & $12.67 \pm 0.29$ & $25.33 \pm 0.76$ & $21.33 \pm 0.76$ & $20.50 \pm 0.87$ & $23.50 \pm 0.50$ \\
\hline $0.01 \mathrm{M} \mathrm{AgNO}_{3}$ & $7.67 \pm 0.58$ & $6.83 \pm 0.29$ & $7.33 \pm 0.29$ & $8.17 \pm 0.58$ & $7.50 \pm 0.50$ \\
\hline Negative control & 0.00 & 0.00 & 0.00 & 0.00 & 0.00 \\
\hline
\end{tabular}

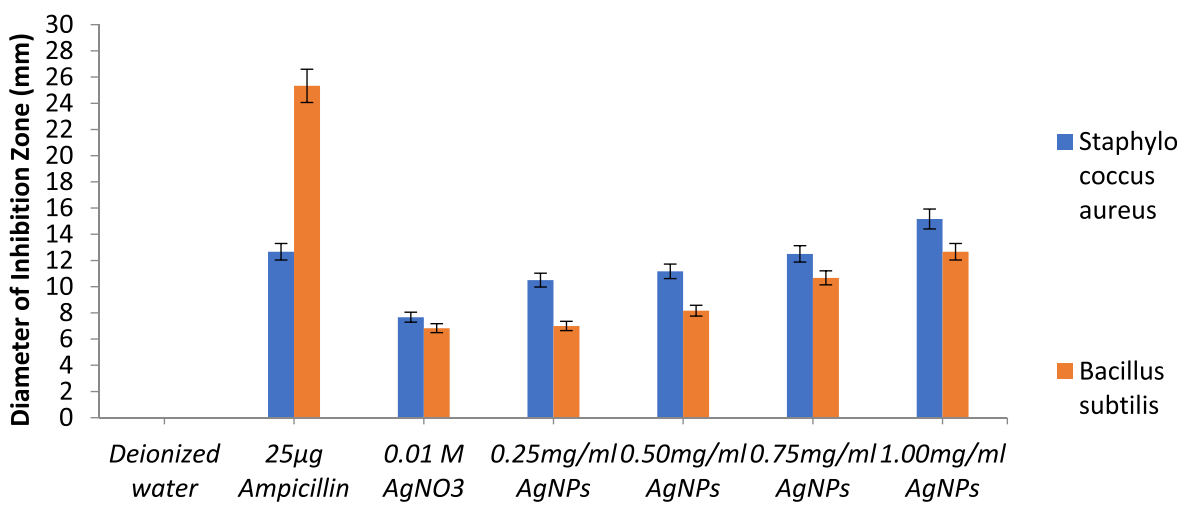

a

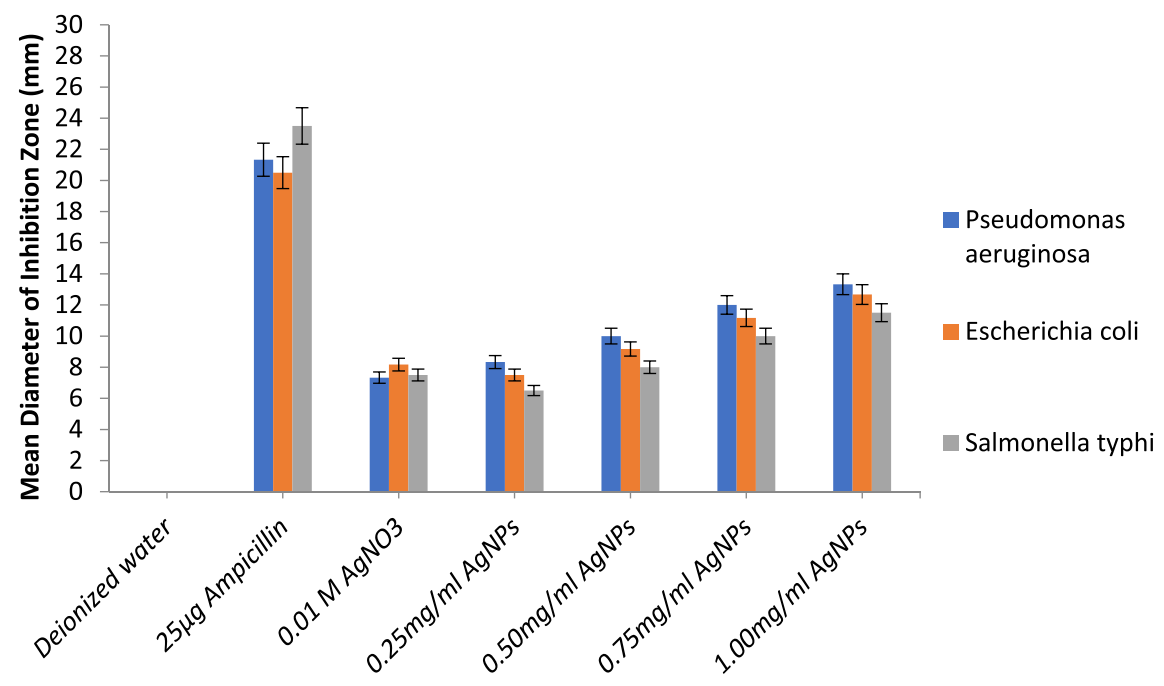

b

Fig. 9 a Comparative anti-bacterial analysis of gram-positive bacteria based on the mean diameter of inhibition zone formed. $\mathbf{b}$ Comparative anti-bacterial analysis of gram-negative bacteria based on the mean diameter of inhibition zone formed 
Table 4 GC-MS analysis of bioactive compounds detected in freeze-dried extract of Padina sp. seaweed

\begin{tabular}{|c|c|c|c|c|c|}
\hline No. & Rt & Name of compounds & Mol. formula & MW & Peak area \% \\
\hline 1 & 4.390 & Cyclotrisiloxane, hexamethyl- & $\mathrm{C}_{6} \mathrm{H}_{18} \mathrm{O}_{3} \mathrm{Si}_{3}$ & 222.46 & 2.23 \\
\hline 2 & 6.931 & Cyclotetrasiloxane, octamethyl- & $\mathrm{C}_{4} \mathrm{H}_{16} \mathrm{O}_{4} \mathrm{Si}_{4}$ & 240.51 & 1.55 \\
\hline 3 & 9.368 & Cyclopentasiloxane, decamethyl- & $\mathrm{C}_{10} \mathrm{H}_{30} \mathrm{O}_{5} \mathrm{Si}_{5}$ & 370.77 & 1.79 \\
\hline 4 & 11.840 & Cyclohexasiloxane, dodecamethyl- & $\mathrm{C}_{12} \mathrm{H}_{36} \mathrm{O}_{6} \mathrm{Si}_{6}$ & 444.92 & 1.69 \\
\hline 5 & 14.089 & Cycloheptasiloxane, tetradecamethy I- & $\mathrm{C}_{14} \mathrm{H}_{42} \mathrm{O}_{7} \mathrm{Si}_{7}$ & 519.08 & 3.24 \\
\hline 6 & 16.653 & Tetradecanoic acid, dodecanoic acid & $\mathrm{C}_{14} \mathrm{H}_{28} \mathrm{O}_{2}$ & 228.37 & 0.91 \\
\hline 7 & 17.814 & Cyclononasiloxane, octadecamethyl- & $\mathrm{C}_{18} \mathrm{H}_{54} \mathrm{O}_{9} \mathrm{Si}_{9}$ & 667.38 & 17.94 \\
\hline 8 & 18.712 & n-Hexadecanoic acid & $\mathrm{C}_{16} \mathrm{H}_{32} \mathrm{O}_{2}$ & 256.42 & 7.03 \\
\hline 9 & 20.561 & Octadecanoic acid, pentadecanoic acid & $\mathrm{CH}_{3}\left(\mathrm{CH}_{2}\right)_{16} \mathrm{CO}_{2} \mathrm{H}$ & 284.48 & 1.06 \\
\hline
\end{tabular}

compounds such as flavonoids and terpenoids. After the reduction of $\mathrm{AgNO}_{3}$, the increases in intensity at $1384.27 \mathrm{~cm}^{-1}$ [6] signified the involvement of nitro compounds into $\mathrm{NO}_{2}$ aliphatic amines [31] in the reduction process. The strong spectral band at $1384.27 \mathrm{~cm}^{-1}$ and $1023.91 \mathrm{~cm}^{-1}$ [11] as observed in Fig. 5c was interpreted for the identification of organic compounds adhering to the silver nanoparticles synthesized as shown in Table 1. Thus, the peptide group can say to play a major role for the reduction of the silver ion into silver nanoparticles.
Therefore, the results revealed that the capping ligand for stabilization of the silver nanoparticles may be amines or alkenes or $\mathrm{O}-\mathrm{H}$ alcohol groups or can be polyphenolic [19] compounds as well.

\subsection{Scanning electron microscopy analysis of silver nanoparticles}

The SEM micrographs of nanoparticles showed that the nanoparticles synthesized were polydispersed spherical shaped, highly distributed with aggregation [21].

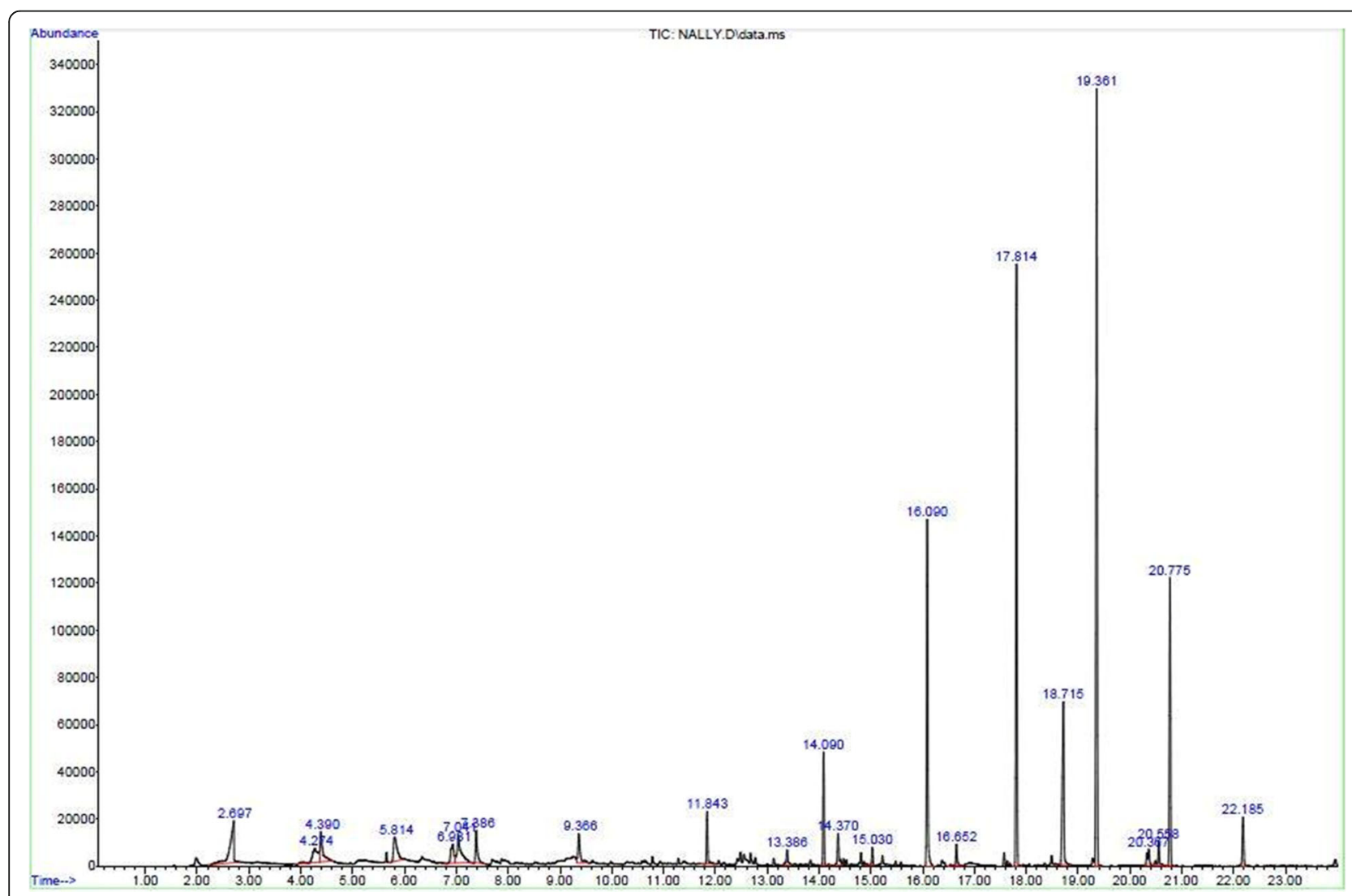

Fig. 10 The GC-MS chromatogram of the freeze-dried extract of Padina sp. seaweed 


\subsection{Field emission scanning electron microscopy analysis} of silver nanoparticles

According to FESEM images obtained, the morphology of silver nanoparticles clearly observed to be within an average size of $40.45 \mathrm{~nm}$ with diameters in the range of $25.0 \mathrm{~nm}$ to $61.4 \mathrm{~nm}$. In addition, the silver nanoparticles formed were predominantly spherical and oval-shaped while some observed to be irregular-shaped and polydispersed. Similarly, in the previous study [32], the elevation in temperature results in the formation of spherical and irregular-shaped nanoparticles of a size of 5-200 nm. Likewise, shape-controlled silver nanoparticles can be synthesized in biological route by varying temperature [33]. A similar result was also recorded by Shivaraj [27] using Padina tetrastomatica extract as reducing and capping agents were observed to synthesize silver nanoparticles with $46 \mathrm{~nm}$ and spherical in morphology.

\subsection{Energy-dispersive X-ray spectrum analysis}

The composition of silver element recorded to be the major component present in silver nanoparticles about $85.02 \mathrm{wt} \%$ as shown in Table 2, followed by chlorine and carbon with $9.04 \%$ and $1.35 \%$, respectively. The presence of chlorine might be due to the aqueous extract of marine algae which was prepared using distilled water and used as a part of the synthesis medium of silver nanoparticles.

\subsection{Antibacterial activity by disc diffusion assay 4.7.1 Antibacterial activity of silver nanoparticles against clinical pathogens}

As shown in Fig. 9a, b, Staphylococcus aureus and Pseudomonas aeruginosa were found to be more susceptible to silver nanoparticle solutions. This finding is in excellent agreement with earlier studies [14] where they recorded the highest inhibition zone for Staphylococcus aureus and Pseudomonas aeruginosa of about $23 \mathrm{~mm}$ and $18 \mathrm{~mm}$, respectively. Moreover, there was no inhibition zone observed for deionized water which acts as a negative control. However, the antibiotic disc of $25 \mu \mathrm{g}$ of ampicillin and $0.01 \mathrm{M}$ of silver nitrate solution was used as a positive control. Almost all the five bacteria were susceptible to the antibiotic ampicillin; however, Bacillus subtilis was highly susceptible towards ampicillin. Unlike Staphylococcus aureus was the least susceptible towards ampicillin. However, the aqueous $0.01 \mathrm{M}$ silver nitrate solution was found to have an unclear and smaller zone of inhibition compared to silver nanoparticles as shown in Fig. 9a, b. This proves that silver is well known for antibacterial properties since Roman time; however, the advances in generating silver nanoparticles (AgNPs) have made possible a revival of the use of silver as a more powerful bactericidal agent $[4,34]$.
Though the mechanism of the bactericidal effect of silver nanoparticles against bacteria is not well understood, however, some studies have suggested that silver nanoparticles may attach to the surface of the cell membrane and thus the power function such as the permeability and respiration get disrupted [35]. It is reasonable to state that the binding of the particles to the bacteria depends on the surface area available for interaction. Some nanoparticles penetrate into the cell and bind with DNA interrupting some gene expression responsible for important metabolism. Smaller particles such as nanoparticles having the larger surface area to the volume ratio which is available for interaction will expose higher bactericidal effect compared to larger particles [36]. The increase of bacterial resistance to antibacterial agents poses a serious problem in the treatment of infectious diseases. In addition, new bacterial strains have increasingly emerged with a dangerous level of resistance, including both gram-positive and gramnegative bacteria. Therefore, there is a high demand for the development of new antibacterial substances in order to prevent the emergence and spreading of multi-resistant bacterial strains.

\subsubsection{Identification of bioactive compounds in freeze-dried extract of Padina sp. marine alga using GC-MS analysis} Hydrazine is an inorganic compound with the formula $\mathrm{N}_{2} \mathrm{H}_{4}$. Hydrazine is mainly used as a foaming agent in preparing polymer foams, but generally, it is widely used as a precursor to polymerization catalysts and pharmaceuticals. However, hydrazine can also be used as an oxygen scavenger to control concentrations of dissolved oxygen to reduce corrosion in conventional electrical power plant [37]. In a biological view, hydrazine can be illustrated as one of the intermediates in the anaerobic oxidation of ammonia (anammox) process. It is produced by some yeasts and the open ocean bacterium known as Brocadia anammoxidans too. Even the most popular edible "button" mushroom, Agaricus bisporus produces organic hydrazine derivatives as well [38].

The GC-MS revealed that the main phycoconstituents were cyclodecasiloxane and cyclononasiloxane. The GC-MS analysis can only be able to cover nonpolar and volatile substances from the extract sample tested; therefore, it is possible to say that bioactive compounds primarily consisting of cyclodecasiloxane may be involved in biological activity and responsible during the reduction process of silver nitrate into silver nanoparticles. The present study can be well justified by comparing the previous review done by Lalitharani et al. [39] which reported that the presence of cyclononasiloxane and octadecamethyl is found to be responsible for the reduction of the $\mathrm{AgNO}_{3}$ and hexadecanoic acid, fatty acid, which acts as a stabilizing agent and thus prevents the aggregation of silver nanoparticles. 
In addition, any one of the fatty acids, hexadecanoic acid (palmitic acid), can also be used to protect the formed silver nanoparticles. Hydrazine and octadecanoic acid also exhibit high antioxidant activity and have the property of anti-inflammatory. Padina sp. marine alga also exhibits a high level of fatty acid diversity and phenolic compounds. A previous study revealed that Padina pavonica crude extract believes to contain abundant of amino acids, fatty acids, vitamins, minerals, phenolic compounds, and carbohydrates [40]. Of which, phenolic compounds especially polyphenols and tannin have reported to have antimicrobial, anti-carcinogenic, and anti-oxidant properties [41].

Even some of the acetic acid, octadecanoic acid, pentadecanoic acid, dodecanoic acid, and 5-benzoylpentanoic acid, which are present in the extract, are major parts of the secondary metabolites which proved to contain medicinal value for the brown algae. The healing properties of these compounds were antioxidants, antiproliferative, anti-invasive, and anti-viral. Most of the brown marine algae are renewable living resources which are also used as food, feed, and fertilizer in many parts of the world due to its ability to contain a great variety of secondary metabolites characterized by a broad spectrum of biological behavior such as antibacterial and antioxidant activities. These compounds usually present in bound states as conjugate with sugars, fatty acids, or proteins. It could be anticipated for the disassociation of conjugate phenolic forms in marine algae as their outer cell wall is much harder. Results showed that the heat processing not only enhanced the contents of biologically active compounds in marine algae but also the biological activity associated with these compounds as compared to the unprocessed marine algae [42].

It is interesting to note that the biosynthesized silver nanoparticles showed higher antibacterial activity compared to the silver metal ions. In our study, the green synthesis of silver nanoparticles from aqueous marine algae extract and its antibacterial activity has been studied. Further research should be carried out on the study of the toxicity of silver nanoparticles, immunity, and mode of action which is necessary for safe and effective exploitation of silver nanoparticles in biomedical, biotechnological, nanotechnology-based industries. Further work should be done to evaluate the antimicrobial effect of silver nanoparticles on normal flora and other beneficial microbes since there is evident proved that the nanoparticles might have cidal effect against even beneficial microbes of normal flora.

\section{Conclusion}

In conclusion, silver nanoparticles synthesized using Padina sp. marine alga extract was stable; it can be an alternative method for chemical synthesis, since this novel green synthesis is a pollutant-free, cost-effective, and eco-friendly synthetic approach. The reduction of silver nitrate $\left(\mathrm{AgNO}_{3}\right)$ was visually confirmed by the change of color from yellowish-brown to reddish-brown after $30 \mathrm{~min}$ of reaction. The silver nanoparticles were characterized using UV-visible spectrophotometer, FTIR spectroscopy, SEM, and FESEM-EDX. The silver SPR band occurred at $420 \mathrm{~nm}$ to $445 \mathrm{~nm}$ steadily increased in absorbance upon increasing time until $48 \mathrm{~h}$ without any shift in peak position (wavelength) confirming the formation of silver nanoparticles. Furthermore, the FT-IR results revealed that the capping ligand for stabilization of the silver nanoparticles may be amines or alkenes or $\mathrm{O}-\mathrm{H}$ alcohol groups or can be polyphenolic compounds as well. According to FESEM images obtained, the morphology of silver nanoparticles distributed within an average size of $40.45 \mathrm{~nm}$ with diameters in the range of $25.0 \mathrm{~nm}$ to $61.4 \mathrm{~nm}$. In addition, the silver nanoparticles formed were predominantly spherical and oval-shaped while some observed to be irregular-shaped and polydispersed. From EDX analysis, the silver element recorded to be the major component present in silver nanoparticle sample with $85.02 \mathrm{wt} \%$. Then, the antibacterial activity of silver nanoparticles by disk diffusion assay against five types of bacteria clearly demonstrates that the bactericidal effect depends on the concentration of the silver nanoparticles. The gram-positive bacteria used in the present study were more effectively controlled by the silver nanoparticles in comparison to gram-negative bacteria where Staphylococcus aureus (in gram-positive) and Pseudomonas aeruginosa (in gram-negative) were found to be more susceptible to silver nanoparticle solutions by forming $15.17 \pm 0.58 \mathrm{~mm}$ and $13.33 \pm 0.76 \mathrm{~mm}$ of diameter of inhibition zone, respectively. Lastly, the identification of bioactive compounds in freeze-dried aqueous extract of Padina sp. marine alga revealed a total of 22 peaks and 25 bioactive compounds. The presence of cyclononasiloxane and octadecamethyl is found to be responsible for the reduction of $\mathrm{AgNO}_{3}$, and hexadecanoic acid acts as a stabilizing agent and thus prevents the aggregation of silver nanoparticles. Marine alga is well known to contain a great variety of secondary metabolites characterized by a broad spectrum of biological behavior such as antibacterial and antioxidant activities. The antibacterial effect of silver nanoparticles showed good bactericidal effect, and therefore, in the future, its property can be well compatible for pharmaceutical and other biomedical applications.

\section{Abbreviations}

AFM: Atomic force microscopy; $\mathrm{AgNO}_{3}$ : Silver nitrate; Ag-NPs: Silver nanoparticles; DLS: Dynamic light scattering; DNA: Deoxyribonucleic acid; EDX: Energy-dispersive X-ray spectroscopy; FESEM: Field emission scanning electron microscopy; FTIR: Fourier transform infrared spectroscopy; GCMS: Gas chromatography and mass spectrometry; $\mathrm{N}_{2} \mathrm{H}_{4}$ : Hydrazine; 
NPS: Nanoparticles; SEM: Scanning electron microscopy; SPR: Surface plasmon resonance; UV: Ultraviolet

\section{Acknowledgements}

The authors acknowledge the Central Laboratory, Universiti Malaysia Pahang, for the characterization of the samples.

\section{Authors' contributions}

PB and NG designed research. MHAR, GPM, RR, and SS conducted the review and editing. Universiti Malaysia Pahang provided funding acquisition, project administration, and resources. PB and SS wrote the paper. And finally, all authors have read and approved the manuscript for publication.

\section{Funding}

The authors gratefully acknowledged the Universiti Malaysia Pahang for the financial assistance through the Internal Research Grant No. RDU1703167 and Flagship Grant No. RDU182205. Author Prakash Bhuyar is thankful to UMP for providing Doctoral Research Scholarship DRS as a financial support.

\section{Availability of data and materials}

The datasets used and analyzed during the current study are available from the corresponding author on reasonable request.

\section{Ethics approval and consent to participate}

Not applicable

\section{Consent for publication}

Not applicable

\section{Competing interests}

The authors declare that they have no competing interests.

\section{Author details}

${ }^{1}$ Algae Culture Collection Center \& Laboratory, Faculty of Industrial Sciences \& Technology, Universiti Malaysia Pahang, Lebuhraya Tun Razak, Kuantan, 26300, Gambang, Pahang, Malaysia. ²Earth Resources and Sustainability Centre (ERAS), Universiti Malaysia Pahang, Lebuhraya Tun Razak, Kuantan, 26300, Gambang, Pahang, Malaysia. ${ }^{3}$ Department of Pathology, Sidra Medicine, 26999 Doha, Qatar. ${ }^{4}$ School of Renewable Energy, Maejo University, Chiang Mai 50290, Thailand.

Received: 10 August 2019 Accepted: 16 December 2019

Published online: 09 January 2020

\section{References}

1. Govindan N et al (2020) Antioxidant and antibacterial activity of red seaweed; Kappaphycus alvarezii against pathogenic bacteria. Glob J Environ Sci Manag 5:1

2. N. Govindan et al. Microalgae cultivation using Palm oil mill effluent as growth medium for lipid production with the effect of $\mathrm{CO} 2$ supply and light intensity. Biomass Convers. Biorefinery, 2019.

3. Govindan N et al (2019) A selective microalgae strain for biodiesel production in relation to higher lipid profile. Maejo Int J Energy Environ Commun. 1(1):8-14

4. Elechiguerra JL et al (2005) Interaction of silver nanoparticles with HIV-1. J. Nanobiotechnology 3:1-10

5. Thangaraju N, Venkatalakshmi RP, Chinnasamy A, Kannaiyan P (2012) Synthesis of silver nanoparticles and the antibacterial and anticancer activities of the crude extract of Sargassum polycystum C. Agardh. Nano Biomed Eng. 4(2):89-94

6. Sahayaraj K, Rajesh S, Rathi JM (2012) Silver nanoparticles biosynthesis using marine alga Padina pavonica (Linn.) and its microbicidal activity. Dig J Nanomater Biostructures 7(4):1557-1567

7. Anjum S, Abbasi BH, Shinwari ZK (2016) Plant-mediated green synthesis of silver nanoparticles for biomedical applications: challenges and opportunities. Pakistan J Bot. 48(4):1731-1760

8. Kannan RRR, Arumugam R, Ramya D, Manivannan K, Anantharaman P (2013) Green synthesis of silver nanoparticles using marine macroalga Chaetomorpha linum. Appl. Nanosci. 3(3):229-233
9. M. Drahansky et al. We are IntechOpen, the world 's leading publisher of Open Access books Built by scientists, for scientists TOP $1 \%$. Intech, vol. i, no. tourism, p. 13, 2016.

10. N. Govindan et al. "Effect of plant hormones on the production of biomass and lipid extraction for biodiesel production from microalgae chlorella sp.," J. Microbiol. Biotechnol. FOOD Sci., vol. 9, no. FEBRUARY - MARCH 2020, p. 4, 2020.

11. Abdel-Raouf N, Al-Enazi NM, Ibraheem IBM, Alharbi RM, Alkhulaifi MM (2018) Biosynthesis of silver nanoparticles by using of the marine brown alga Padina pavonia and their characterization. Saudi J Biol Sci. 26(6):1207-1215

12. Kumar P, Senthamil Selvi S, Govindaraju M (2013) Seaweed-mediated biosynthesis of silver nanoparticles using Gracilaria corticata for its antifungal activity against Candida spp. Appl Nanosci. 3(6):495-500

13. A. L. G. Ae, A guide for the identification of microscopic algae in South African freshwaters, no. May. 2006.

14. B. R. S and R. Rajasekaran, "Biosynthesis of silver nanoparticles and its antibacterial activity using seaweed Urospora sp.," African J Biotechnol., vol. 11, no. 58, pp. 12192-12198, 2012.

15. Senthilkumar P, Sudha S (2012) Antioxidant and antibacterial properties of methanolic extract of green seaweed Chaetomorpha linum from gulf of mannar: Southeast coast of India. Jundishapur J Microbiol. 5(2):411-415

16. Vijayan SR, Santhiyagu P, Singamuthu M, Kumari Ahila N, Jayaraman R, Ethiraj K (2014) Synthesis and characterization of silver and gold nanoparticles using aqueous extract of seaweed, turbinaria conoides, and their antimicrofouling activity. Sci. World J 2014

17. Kora AJ, Manjusha R, Arunachalam J (2009) Superior bactericidal activity of SDS capped silver nanoparticles: synthesis and characterization. Mater Sci Eng C 29(7):2104-2109

18. Nabikhan A, Kandasamy K, Raj A, Alikunhi NM (2010) Synthesis of antimicrobial silver nanoparticles by callus and leaf extracts from saltmarsh plant, Sesuvium portulacastrum L. Colloids Surfaces B Biointerfaces 79(2):488-493

19. Vijayabaskar P, Shiyamala V (2012) Antioxidant properties of seaweed polyphenol from Turbinaria ornata (Turner) J. Agardh, 1848. Asian Pac J Trop Biomed. 2(1 Suppl):S90-\$98

20. D'Souza L, Devi P, Divya Shridhar MP, Naik CG (2008) Use of Fourier transform infrared (FTIR) spectroscopy to study cadmium-induced changes in Padina tetrastromatica (Hauck). Anal Chem Insights 2008(3):135-143

21. Puchalski M, Dabrowski P, Olejniczak W, Krukowski P, Kowalczyk P, Polański K (2007) The study of silver nanoparticles by scanning electron microscopy, energy dispersive $\mathrm{X}$-ray analysis and scanning tunnelling microscopy. Mater Sci Pol. 25(2):473-478

22. Kannan S (2014) FT-IR and EDS analysis of the seaweeds Sargassum wightii and Gracilaria corticata (red algae). Int J Curr Microbiol Appl Sci 3(4):341-351

23. Pugazhenthiran N, Anandan S, Kathiravan G, Udaya Prakash NK, Crawford S, Ashokkumar M (2009) Microbial synthesis of silver nanoparticles by Bacillus sp. J Nanoparticle Res. 11(7):1811-1815

24. Kim JS et al (2007) Antimicrobial effects of silver nanoparticles. Nanomedicine Nanotechnol Biol Med. 3(1):95-101

25. Bönnemann $\mathrm{H}$, Richards RM (2001) Nanoscopic metal particles - synthetic methods and potential applications. Eur J Inorg Chem 2001(10):2455

26. Hamed SM, Hagag ES, El-Raouf NA (2019) Green production of silver nanoparticles, evaluation of their nematicidal activity against Meloidogyne javanica and their impact on growth of faba bean. Beni-Suef Univ J Basic Appl Sci 8(1)

27. R. Shivaraj, Green synthesis of silver nanoparticles from extract of. 7, 3, 991998,2012

28. Patil V, Sastry M (1997) Electrostatically controlled diffusion of carboxylic acid derivatized Q-state CdS nanoparticles in thermally evaporated fatty amine films. J Chem Soc Faraday Trans. 93(24):4347-4353

29. Mukherjee $P$ et al (2001) Fungus-mediated synthesis of silver nanoparticles and their immobilization in the mycelial matrix: A Novel Biological Approach to Nanoparticle Synthesis. Nano Lett. 1(10):515-519

30. Shankar SS, Rai A, Ahmad A, Sastry M (2004) Rapid synthesis of Au, Ag, and bimetallic Au core-Ag shell nanoparticles using Neem (Azadirachta indica) leaf broth. J Colloid Interface Sci. 275(2):496-502

31. Ponnanikajamideen M, Malini M, Malarkodi C, Rajeshkumar S (2014) Bioactivity and phytochemical constituents of marine brown seaweed (Padina tetrastromatica) extract from various organic solvents. Int J Pharm Ther. 5(2):108-112

32. Lengke MF, Fleet ME, Southam G (2007) Biosynthesis of silver nanoparticles by filamentous cyanobacteria from a silver(I) nitrate complex. Langmuir 23(5):2694-2699 
33. Bansal V, Bharde A, Ramanathan R, Bhargava SK (2012) Inorganic materials using 'unusual' microorganisms. Adv Colloid Interface Sci. 179-182:150-168

34. Bhuyar P, Zagade S, Revankar R, Yusoff MM, Ab-Rahim MH (2018) Isolation, characterization and partial purification of keratinase from keratinolytic bacteria. Sch J Appl Sci Res. 1(6):40-45

35. Slavin YN, Asnis J, Häfeli UO, Bach H (2017) Metal nanoparticles: understanding the mechanisms behind antibacterial activity. J Nanobiotechnology 15(1):1-20

36. Darroudi M, Ahmad MB, Mashreghi M (2014) Gelatinous silver colloid nanoparticles: synthesis, characterization, and their antibacterial activity. J Optoelectron Adv Mater. 16(1-2):182-187

37. Strous M, Jetten MSM (2004) Anaerobic oxidation of methane and ammonium. Annu Rev Microbiol. 58(1):99-117

38. Dietl A et al (2015) The inner workings of the hydrazine synthase multiprotein complex. Nature 527(7578):394-397

39. Lalitharani S, Mohan VR, Regini GS, Kalidass C (2009) GC-MS analysis of ethanolic extract of Pothos scandens leaf. J Herb Medi Toxicol. 3(2):159-160

40. Yang Jl et al (2012) Aqueous extracts of the edible Gracilaria tenuistipitata are protective against $\mathrm{H} 2 \mathrm{O} 2$-induced DNA damage, growth inhibition, and cell cycle arrest. Molecules 17(6):7241-7254

41. Arunkumar K, Sivakumar SR, Rengasamy R (2010) Review on bioactive potential in seaweeds (Marine Macroalgae): a special emphasis on bioactivity of seaweeds against plant pathogens. Asian J Plant Sci 9(5):227240

42. G. Rajauria, "Antioxidant capacity and polyphenol content of brown seaweeds after heat processing," J. Food Sci., no. March, pp. 2-3, 2010.

\section{Publisher's Note}

Springer Nature remains neutral with regard to jurisdictional claims in published maps and institutional affiliations.

\section{Submit your manuscript to a SpringerOpen ${ }^{\circ}$ journal and benefit from:}

- Convenient online submission

- Rigorous peer review

- Open access: articles freely available online

High visibility within the field

- Retaining the copyright to your article

Submit your next manuscript at $\boldsymbol{\nabla}$ springeropen.com 